Original article

\title{
COMPARATIVE ANALYTICAL STUDY OF THE MATERIALS USED IN WALL PAINTING OF HISTORICAL PALACES
}

\author{
Ali M. F. and Darwish S. S. \\ Department of Conservation, Faculty of Archaeology, Cairo University, Egypt \\ amanymbakr@hotmail.com
}

\begin{abstract}
Historical palaces are adorned with valuable wall paintings which were applied by tempera techniques. These techniques were directly applied on the wall or after preparing the surface with a canvas layer. Most of these wall paintings suffered from several deterioration aspects such as cracking, loss of paint layers, and formation of color stains due to biological or salt effects. The chemical composition of the materials used in the construction and decoration of the wall paintings were studied by means of light optical microscope (L.O.M), fourier transform infrared spectroscopy $(F T$-IR), atomic absorption spectrophotometry (A.A.) and X-ray diffraction spectroscopy (XRD). The obtained results will be used to lay out a scientific plan for restoration and preservation.
\end{abstract}

Keywords: Wall painting, pigments, binding media, Abdeen Palace, XRD, FTIR.

\section{Introduction}

There are a substantial number of studies that have been published on the different materials used in Egyptian wall painting [1] [2]. Due to natural aging and many other factors, these works of art suffer now from various deterioration aspects. The most common damage is found in the paint layer as a result of moisture variations. Where an excess of organic binder is used, the paint flakes from the under painting with thick layers dropping off in small particles. In other cases the medium disintegrates, resulting in a loss of cohesion and powdering of the paint layer. Small scale spot formations, related to the effects of moisture occur relatively often; whether they are alterations to the pigment or to the organic medium is a point that must still be determined scientifically.
Graying in the paint layer may be caused by sintering or by a cracked binding agent. The microbiological infestation can be seen in varying concentrations causing discoloration often associated with detachment of the paint layer [3] [4] [5]. Case One (Abdeen Palace): It is one of the official residences of the President of Egypt. Its construction started in 1863 and continued for 10 years, and the palace was officially inaugurated in 1874. It was erected on an area of 24 feddans. However, the palace's garden was added in 1921 by Sultan Fuad I on an area of 20 feddans. The palace is considered one of the most sumptuous palaces in the world in terms of its adornments, paintings, and large number of clocks scattered in the parlors and wings, most of which are decorated with 
pure gold. Abdeen Palace was so called as it was built on the debris of a house owned by the Turkish Prince Abdeen Bey. Some parts of the wall painting in Abdeen Palace were perfectly preserved, while in others, there were powdering or flaking paints. In some area the painting layer was entirely lost, but the plaster survived in good condition while in other large areas, there was a complete loss of plaster. Moreover, there were considerable portions in danger of further loss as a result of separation of the painted plaster from the wooden support of the ceiling, fig. (1- a, b, c). Case Two (EI Safa Palace): It was built by Prince Mohamed Ali in 1939 in Alexandria. To the right side of the palace, there is a big tea hall, whose length is $45 \mathrm{~m}$ and contains beautiful oil wall paintings of famous old palaces in Istanbul. Wall paintings in this palace suffer from many aspects of deterioration such as cracking and loss of some of the paint and binding layers, fig. (2). The aim of this work is to identify the composition of the materials used in the construction and decoration of the wall painting in Abdeen palace in Cairo and El Safa palace in Alexandria, and study the techniques applied as well as the state of deterioration. The obtained results will be used to lay out a scientific plan for restoration and preservation.
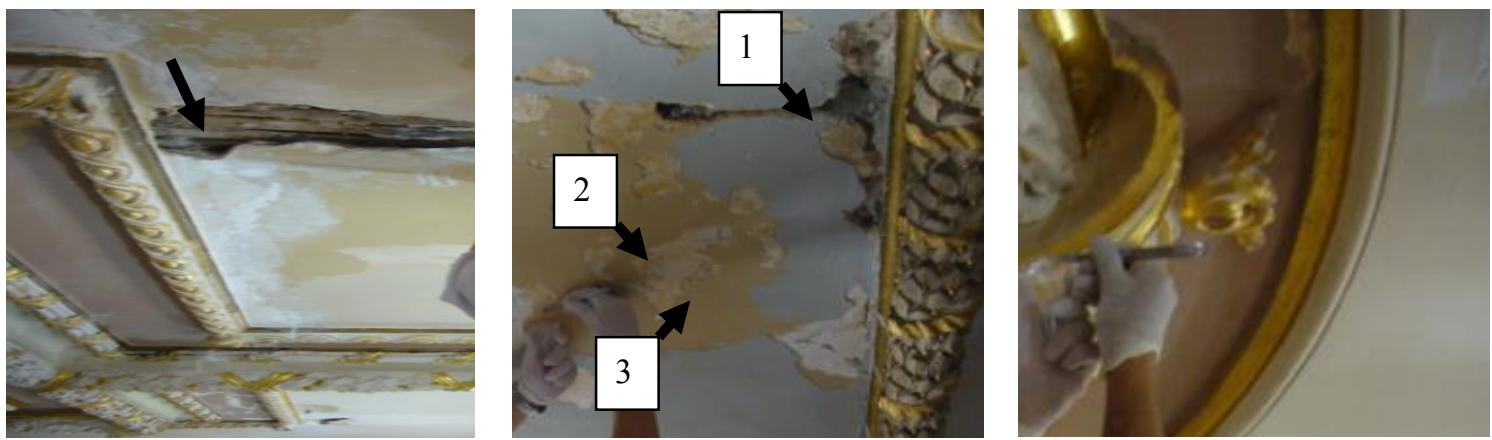

Figure (1) Show a Separation of all layers from the wooden support in the ceiling of Abdeen Palace, b samples from the paint layer Of Abdeen Palace: $1=$ green colour, $2=$ creamy yellow colour, $3=$ brown colour, $\mathrm{c}$ the gilded parts Of the ceiling Of Abdeen Palace.
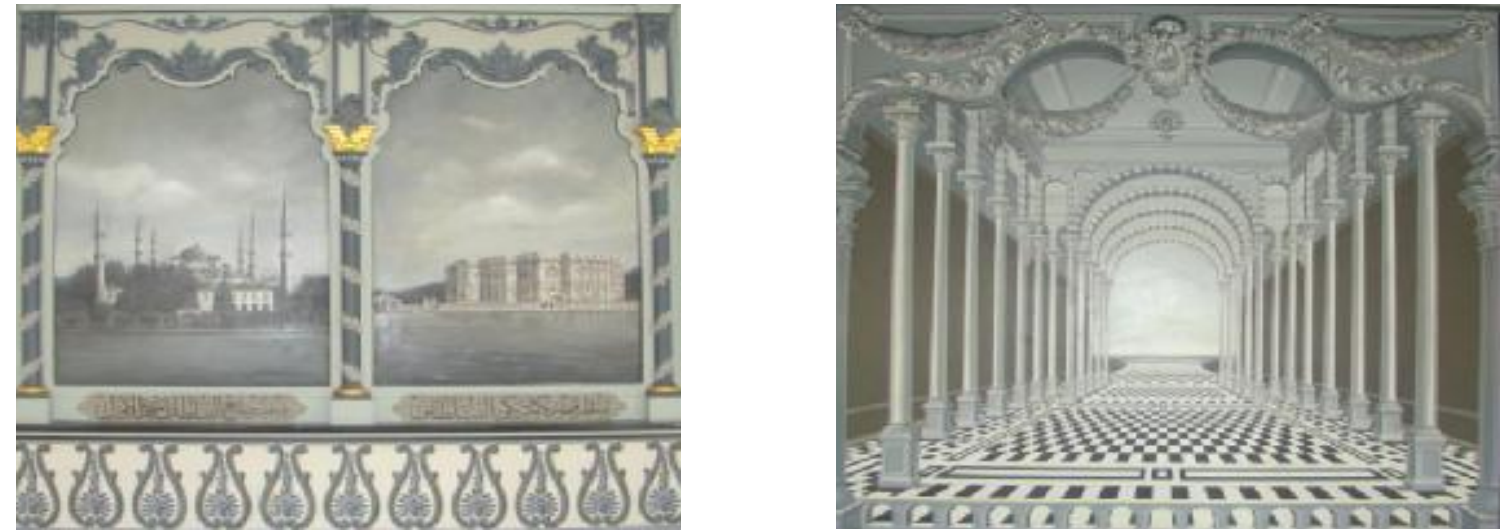

Figure (2) Show Oil wall painting of tea hall in El Safa Palace

\section{Materials and methods:}

\subsection{Samples}

Due to the destructive nature of sampling, samples were carefully chosen from areas that had no aesthetic or iconographic value for future

reconstruction and from areas which suffer from deterioration. Samples were then subjected to examination and analysis. 
2.1.1. Samples from Abdeen palace:

- Mortar samples (1A, 1B, 1C) which bind among the wooden support, the ground and the paint layers. - Ground layers $(2 \mathrm{~A}, 2 \mathrm{~B}, 2 \mathrm{C})$ - Paint layers

\subsubsection{Samples from El Safa Palace:}

- Paint layers (sky color (light blue), greenish blue color, black color\} -

\subsection{Methods:}

\subsubsection{L.O.M. Examination}

The samples were prepared as follows: they were cut impregnated in epoxy 812 2.2.2. Atomic Absorption (A.A.)

Samples were weighed and dissolved in minimum amount of hydrochloric acid. Small amount of deionized water was added, then filtered. The volumes of the filtrates were completed to $100 \mathrm{ml}$ by 2.2.3. X-ray diffraction (XRD)

Some samples were investigated and carried out using X-ray diffraction 2.2.4. FTIR analysis

The samples were analyzed as $\mathrm{KBr}$ pellets by JASCO FT\IR-460 plus

\section{Results and Discussion}

\subsection{Mortar samples}

In Abdeen Palace, the results of A.A. analysis in table (1) show that the mortar samples (1A, 1B, 1C) contain high percentage of insoluble components, in addition to sodium and calcium. The results of XRD, table ( $3 \mathrm{a}, \mathrm{b}, \mathrm{c})$, fig. (3a, $b, c)$ confirmed these results, the mortar samples contain quartz $\mathrm{SiO}_{2}$ which may be present in the soft ground or fillers

\subsection{The preparation layers}

In Abdeen Palace, XRD analysis in fig show that the ground layers underneath the paint layers contain mainly gypsum mixed with calcite, in addition to quartz below the yellow color, in addition to two crystalline phases of gypsum mainly present in ground layer below the green color. Some gypsum is converted to anhydrite as a result of drought in ground layer below the brown color. In El Safa Palace, the results of A.A. in table (2) show that the preparation layer contains a
$(3 \mathrm{~A}=$ creamy yellow color, $3 \mathrm{~B}=$ green color, $3 \mathrm{C}=$ brown color) - Gilded layers (4A, 4B, 4C) - Ground below the gilded layer $(5 \mathrm{~A}, 5 \mathrm{~B}, 5 \mathrm{C})$

Ground layers below the three tested colors - Canvas sample

and mounted. Specimens are polished with rotating discs of abrasive paper

deionized water and analyzed for calcium $\left(\mathrm{Ca}^{2+}\right)$, magnesium $\left(\mathrm{Cu}^{2+}\right)$, sodium $\left(\mathrm{Na}^{+}\right)$, iron $\left(\mathrm{Fe}^{3+}\right)$, zinc $\left(\mathrm{Zn}^{+2}\right)$ and lead $\left(\mathrm{Pb}^{+2}\right)$ using Perkin Elmer A. analyst 100 spectrophotometer.

Philips PW 1840 diffractometer with $\mathrm{Cu}$ radiation.

spectrometer, in the transmission mode (400-4000 $\mathrm{cm}^{-1}, 4 \mathrm{~cm}^{-1}$ resolution).

added to the mortar, gypsum $\mathrm{CaSO}_{4} \cdot 2 \mathrm{H}_{2} \mathrm{O}$ (the main component of mortar) and calcite $\mathrm{CaCO}_{3}$ which is mixed with gypsum. Sodium is found as halite $\mathrm{NaCl}$ whose presence is due to materials used in the ground layer or salty water which leaked through the ceiling and the wall.

high percentage of zinc in addition to calcium and lead indicating that the preparation layer is a mixture of zincite $\mathrm{ZnO}$, cerussite $\mathrm{PbCO}_{3}$ (lead white) and gypsum $\mathrm{CaSO}_{4} \cdot 2 \mathrm{H}_{2} \mathrm{O}$. Spectrum of XRD analysis in fig ( $4 \mathrm{a}, \mathrm{b}, \mathrm{c}, \mathrm{d}, \mathrm{e}, \mathrm{f})$ confirmed that the preparation layer is a mixture of gypsum and zincite. Conversion of part of the gypsum to anhydrite in the preparation layer underneath the greenish blue color was a result of drought in some parts of the painting. 


\subsection{The paint layers}

In Abdeen Palace, A.A. results in table

(1) show that the paint samples (3A, 3B,

3C) contain high percentage of lead and zinc in sample 3A (creamy yellow color) in addition to a small percent of sodium in sample 3B (green color) and iron in sample 3C (brown color). From the previous results and XRD analysis in table (3), \& fig (3a, b, c, d) it could be concluded that:

1) Creamy yellow color is produced by mixing yellow lead oxide, mussicot $\mathrm{PbO}$ with white zinc, zincite, $\mathrm{ZnO}$. The examination of yellow color by L.O.M. (fig 5a) showed that the color and the preparation layers are inhomogeneous in thickness, most probably due to inadequate preparation of the paint layers or presence of over painting layers at different periods. There were also black spots in the coarse mortar layer due to the additives that were mixed with it.

2) Green color, the paint granules of green color were undefined by L.O.M. (fig $5 b)$. The color may be a modern plastic material containing a small percent of paratacamite $\mathrm{Cu}_{2} \mathrm{Cl}(\mathrm{OH})_{3}$ whose presence was proved by XRD analysis, table ( $3 \mathrm{a}, \mathrm{b}$, c) According to Fleet (1975) [6] and Jambor, et al. (1996) [7] paratacamite was used as green color. Paratacamite may be involved in the original composition of the color or resulting from the interaction of halite with free copper involved in the composition of the modern plastic color in presence of moisture. Presence of halite is due to materials used in the ground layer or salty water that leaked through the ceiling and the walls.

3) Brown color, examination of the brown color by L.O.M., fig $(5 \mathrm{c})$ showed more than one paint layer. The paint layer is very thin and tends to be red, which was confirmed by the presence of iron through A.A, table (1) and XRD, table (3 a, b, c).

\subsection{The gilded layers:}

The examination of the gilded layer in the ceiling of Abdeen Palace by L.O.M. showed irregular shapes of the gold plates and presence of resinous-looking
This proved that Iron oxide (hematite) is responsible for the brown color. Similar results were obtained by Hradil, et al. (2003) [8] and Cornell and Schwertmann (1996) [9]. L.O.M. also showed the high homogeneity of the color underneath the layer (the fine plaster layer) and the grains shape of the mortar layer, which resulted from the coarse particles in its structure.

In El Safa Palace, A.A., table (2) results showed that both the sky color and greenish blue color contain a moderate amount of zinc in addition to calcium and a small amount of iron, while the black color was not detected by atomic absorption analysis. The examination of the paint layer, fig ( $4 \mathrm{a}, \mathrm{b} \& \mathrm{c}$ ) and XRD analysis showed that:

1) Sky color (light blue), appeared under the microscope as grayish blue. This color was formed by mixing Prussian blue $\mathrm{Fe}_{4}\left[\mathrm{Fe}(\mathrm{Cn})_{6}\right]_{3}$ with a white color (may be gypsum or zincite). According to Getten and Stout (1966) [10], Prussian blue was used to obtain blue color.

2) The greenish blue color appeared under the microscope as turquoise which is a mixture of Prussian blue and chrome green Viridian $\mathrm{Cr}_{2} \mathrm{O}_{3}$ in the presence of zincite and gypsum.

3) The black color, the examination of the black color by L.O.M, fig (6-a, b, c, d) showed more than one paint layer. The color layer is very thin and tends to be blue confirming the presence of carbon with blue particles residue. XRD analysis proved that no crystalline phases related to carbon black (graphite) or other minerals typically used to obtain a black color are present, and amorphous carbon may have been used for the black color as mentioned by Winter,1983 [11].

material (glue) which was used in the fixation of the gold paper as well as a white layer underneath the gilded layer in some areas, fig (5d). The results of 
A.A. of the gilded layers showed high percentage of zinc and low percentage of copper in both 4A and 4B samples indicating that the gilded layer may be gold paper containing copper and zinc as impurities, while, sample 4C contained moderate amounts of copper and zinc indicating that the gilded layer may be brass, $\mathrm{Cu}-\mathrm{Zn}$ alloy. These results were confirmed by XRD analysis

Table (1) Show atomic absorption results of samples taken from mortar, paint\& gilded layers of Abdeen Palace

\begin{tabular}{|c|c|c|c|c|c|c|c|}
\hline \multirow{2}{*}{ Sample } & $\mathbf{C u}^{+\mathbf{+}}$ & $\mathbf{F e}^{+\mathbf{3}}$ & $\mathbf{Z n}^{+\mathbf{2}}$ & $\mathbf{C a}^{+\mathbf{2}}$ & $\mathbf{N a}^{+}$ & $\mathbf{P b}^{+\mathbf{2}}$ & Insoluble \% \\
\hline 1A & -- & -- & -- & 1309 & 1704 & -- & 56.21 \\
\hline 1B & -- & -- & -- & 1140 & 2470 & -- & 59.30 \\
\hline 1C & -- & -- & -- & 2215 & 3246 & -- & 51.69 \\
\hline 3A & -- & -- & 961.10 & -- & -- & 113.40 & -- \\
\hline 3B & 0.086 & 10.88 & -- & -- & 345 & -- & -- \\
\hline 3C & -- & 15.59 & -- & -- & -- & -- & -- \\
\hline 4A & 2.508 & -- & 327.4 & -- & -- & -- & -- \\
\hline 4B & 0.264 & -- & 770.1 & -- & -- & -- & -- \\
\hline 4C & 9.049 & -- & 316.2 & -- & -- & -- & - \\
\hline
\end{tabular}

Table (2) Show atomic absorption Results of samples taken from ground \& paint layers of El Safa

\begin{tabular}{|c|c|c|c|c|c|c|c|}
\hline Sample & Conc. & $\mathrm{Fe}^{+3}$ & $\mathrm{Co}^{+2}$ & $\mathrm{Ca}^{+2}$ & $\mathbf{P b}^{+2}$ & $\mathbf{Z n}^{+2}$ & $\mathrm{Cu}^{+2}$ \\
\hline Ground of Heaven color & \multirow{6}{*}{ 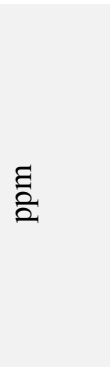 } & -- & -- & 1.740 & 1.536 & 49.69 & -- \\
\hline Heaven color & & 2.326 & 0.177 & 1.740 & 1.536 & 49.69 & 0.205 \\
\hline Ground of the greenish blue color & & -- & -- & 1.740 & 0.937 & 32.96 & -- \\
\hline greenish blue color & & 3.041 & 0.209 & 1.802 & 0.937 & 32.96 & 0.82 \\
\hline Ground of black color & & -- & -- & 1.802 & 1.075 & 12.46 & -- \\
\hline Black color & & 0.562 & 0.107 & 1.802 & 1.075 & 12.46 & 0.82 \\
\hline
\end{tabular}

Table (3-a) Show X-ray diffraction (XRD) results of Abdeen Palace \& El Safa Palaces

\begin{tabular}{|c|c|c|c|c|c|c|c|c|c|}
\hline Mineral \% & 1a & 1b & 1c & $2 \mathbf{a}$ & $2 \mathbf{b}$ & 2c & 3a & $\mathbf{3 b}$ & $3 c$ \\
\hline Gypsum $\left(\mathrm{CaSO}_{4} \cdot 2 \mathrm{H}_{2} \mathrm{O}\right)$ & 53.45 & 56.04 & 62.6 & 54.58 & 40.49 & 62.57 & -- & -- & 41.55 \\
\hline Calcite $\left(\mathrm{CaCO}_{3}\right)$ & 34.27 & 30.58 & 31.2 & 32.69 & 19.02 & 22,39 & 22.39 & 72.07 & 49.10 \\
\hline Quartz $\left(\mathrm{SiO}_{2}\right)$ & 21.67 & 13.38 & 6.14 & 12.73 & -- & -- & 6.67 & 6.08 & -- \\
\hline Anhydrite $\left(\mathrm{CaSO}_{4} \cdot 1 / 2 \mathrm{H} 2 \mathrm{O}\right)$ & -- & -- & -- & -- & -- & 14.86 & -- & -- & -- \\
\hline Prussian Blue $\mathrm{Fe}\left\{\mathrm{Fe}(\mathrm{CN})_{6}\right\}_{3}$ & -- & -- & -- & -- & -- & 14.86 & -- & -- & -- \\
\hline Zinc oxide $\mathrm{ZnO}$ & -- & -- & -- & -- & -- & -- & 53.04 & -- & -- \\
\hline Mussicot $\mathrm{PbO}$ & -- & -- & -- & -- & -- & -- & 8.44 & -- & -- \\
\hline Viridian $\left(\mathrm{PbCrO}_{4}\right)$ & -- & -- & -- & -- & -- & -- & -- & -- & -- \\
\hline Paratacmite $\left(\mathrm{Cu}(\mathrm{OH})_{3} \mathrm{Cl}\right.$ & -- & -- & -- & -- & -- & -- & -- & 15.85 & -- \\
\hline Hematite $\left(\mathrm{Fe}_{2} \mathrm{O}_{3}\right)$ & -- & -- & -- & -- & -- & -- & -- & -- & 15.35 \\
\hline Gold (Au) & -- & -- & -- & -- & -- & -- & -- & -- & -- \\
\hline Brass (Cu Zn) & -- & -- & -- & -- & -- & -- & -- & -- & -- \\
\hline Halite (Na CL) & -- & -- & -- & -- & -- & -- & -- & 6.00 & -- \\
\hline
\end{tabular}


Table (3-b) Show X-ray diffraction (XRD) results of Abdeen Palace \& El Safa Palaces

\begin{tabular}{|l|c|c|c|c|c|c|}
\hline \multicolumn{1}{|c}{ Mineral \% } & $\mathbf{4 a}$ & $\mathbf{4 b}$ & $\mathbf{4 c}$ & $\mathbf{5 a}$ & $\mathbf{5 b}$ & $\mathbf{5 c}$ \\
\hline Gypsum $\left(\mathrm{CaSO}_{4} \cdot 2 \mathrm{H}_{2} \mathrm{O}\right)$ & 49.35 & 27.04 & 41.55 & 45.10 & 47.28 & 47.8 \\
\hline Calcite $\left(\mathrm{CaCO}_{3}\right)$ & -- & -- & -- & -- & -- & -- \\
\hline Quartz $\left(\mathrm{SiO}_{2}\right)$ & -- & -- & -- & -- & -- & -- \\
\hline Anhydrite $\left(\mathrm{CaSO}_{4} \cdot 1 / 2 \mathrm{H} 2 \mathrm{O}\right)$ & -- & 10.58 & 41.55 & -- & 5.44 & 4.38 \\
\hline Prussian $\mathrm{Blue} \mathrm{Fe}\left\{\mathrm{Fe}(\mathrm{CN})_{6}\right\}_{3}$ & -- & 10.58 & 14.86 & -- & 5.44 & 4.38 \\
\hline Zinc oxide $\mathrm{ZnO}$ & 41.60 & 57.53 & 53.40 & -- & -- & -- \\
\hline Mussicot $\mathrm{PbO}$ & -- & -- & -- & -- & -- & -- \\
\hline Viridian $(\mathrm{PbCrO}$ & - & -- & - & - \\
\hline Paratacmite $\left(\mathrm{Cu}(\mathrm{OH})_{3} \mathrm{Cl}\right.$ & -- & -- & -- & -- & -- & -- \\
\hline Hematite $\left(\mathrm{Fe} \mathrm{O}_{3}\right)$ & -- & -- & -- & -- & -- & -- \\
\hline Gold $(\mathrm{Au})$ & -- & -- & -- & -- & -- & -- \\
\hline Brass $(\mathrm{Cu} \mathrm{Zn})$ & 9.05 & 4.83 & -- & -- & -- & -- \\
\hline Halite $(\mathrm{Na} \mathrm{CL})$ & -- & -- & 12.74 & -- & -- & -- \\
\hline
\end{tabular}

Table (3-c) Show X-ray diffraction (XRD) results of Abdeen Palace \& El Safa Palaces

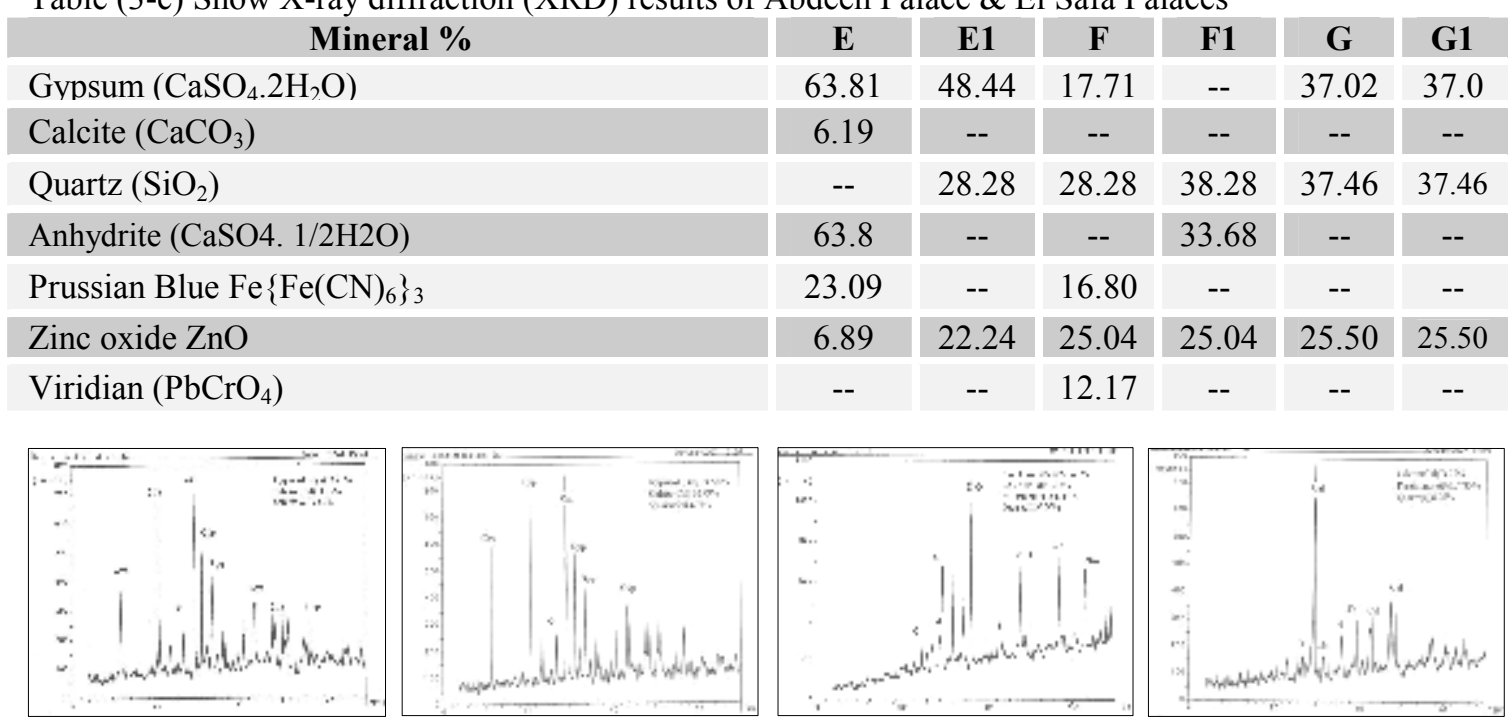

Fig 3: Shows XRD pattern of the paint \& ground layers of Abdin Palace $\underline{\mathbf{a}}$ mortar, $\underline{\mathbf{b}}$ plaster layer, $\underline{\mathbf{c}}$ yellow pigment, $\underline{\mathbf{d}}$ Green pigment
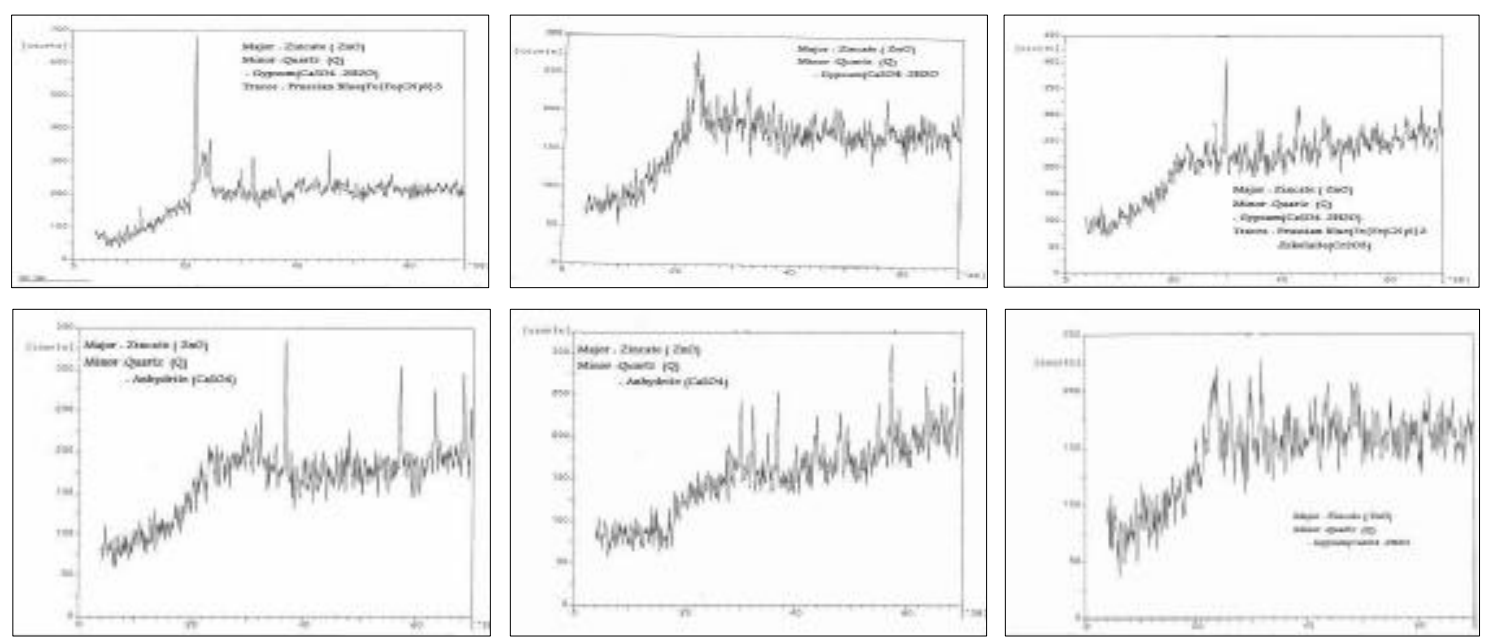

Fig 4: Shows XRD pattern of the paint \& ground layers of El Safa Palace $\underline{\mathbf{a}}$ sky colour E, $\underline{\mathbf{b}}$ ground E1below the sky colour, $\underline{\mathbf{c}}$ greenish blue colour F, $\underline{\mathbf{d}}$ ground below the greenish blue colour F1, $\underline{\mathbf{e}}$ black colour $\mathrm{G}, \underline{\mathbf{f}}$ ground below the black colour G1 

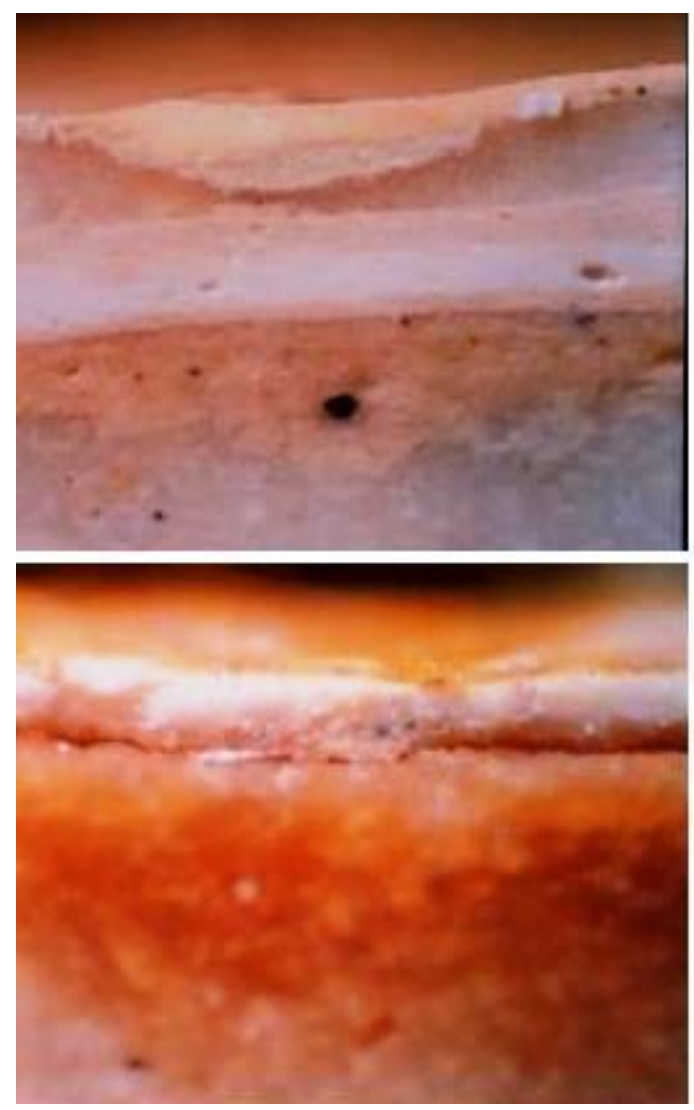

Fig.5: Show photomicrographs of the paint and gilded layers of Abdeen Palace $\underline{\mathbf{a}}$ yellow colour, $\underline{\mathbf{b}}$ green colour, $\underline{\mathbf{c}}$ brown colour, $\underline{\mathbf{d}}$ gilded layer
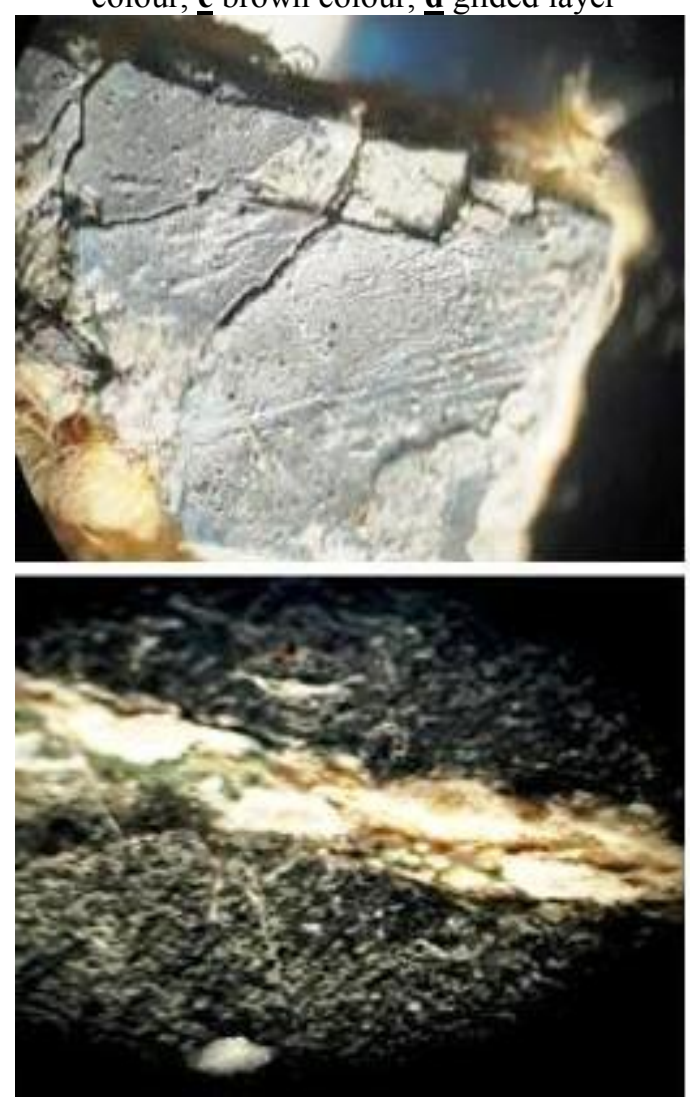
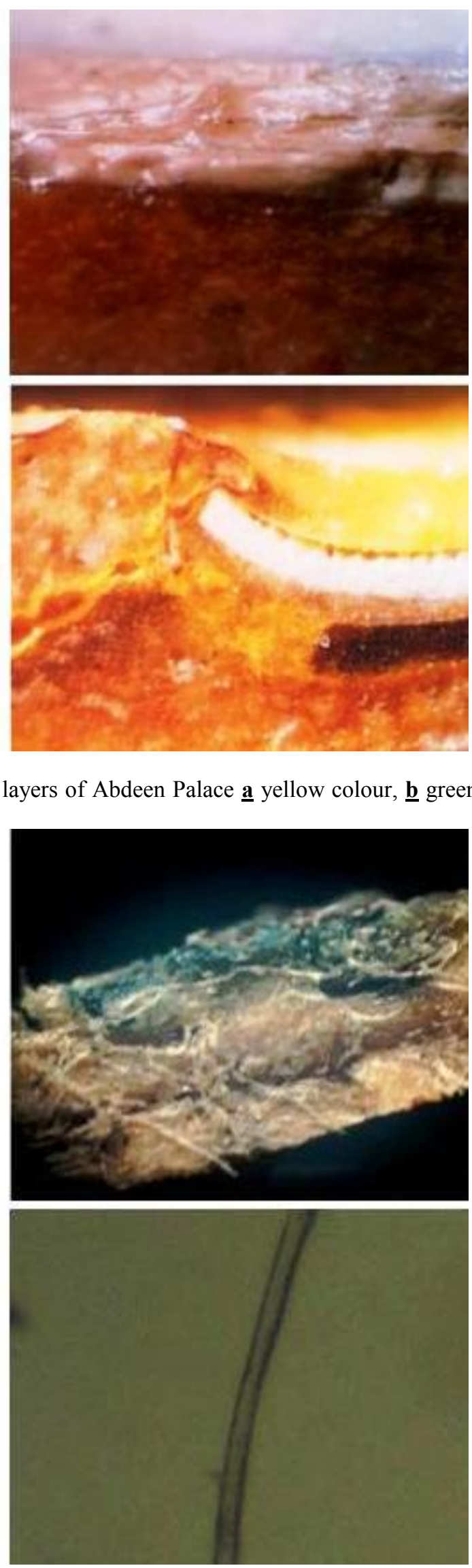
Fig.6: Shows photomicrographs of the paint layer and canvas fiber of El Safa Palace $\underline{\mathbf{a}}$ sky colour $\underline{\mathbf{b}}$ greenish blue colour $\underline{\mathbf{c}}$ the black colour $\underline{\mathbf{d}}$ the canvas fiber

\subsection{The binder:}

In Abdeen Palace: The results of FTIR showed that animal glue was used to bind paint grains and fix the gilded layer as shown in table (4), fig. (7 a, b) The samples spectra were compared with that of animal glue, $50 \%$ (calcium carbonate + animal glue) and gypsum standards [12]. In El Safa Palace: Samples from the sky and greenish blue colors were analyzed to identify the binders used with these colors. The results were compared with standard samples of both animal glue and vegetable oil (flax seed oil). Results showed that the tested samples have a high proportion of animal glue with a proportion of flax seed oil table (5), fig. (8) [12].

Table (4): FTIR results of paint \& gilded layers in Abdeen Palace

\begin{tabular}{|c|c|c|c|c|c|c|}
\hline \multicolumn{6}{|c|}{ Wave number $\left(\mathrm{cm}^{-1}\right)$} & \multirow{3}{*}{ Functional groups \& comment } \\
\hline \multicolumn{3}{|c|}{ Paint layer } & \multicolumn{3}{|c|}{ Gilded layer } & \\
\hline $3 \mathrm{~A}$ & 3B & $3 \mathrm{C}$ & $4 \mathrm{~A}$ & 4B & $4 \mathrm{C}$ & \\
\hline $\begin{array}{c}3545 \\
3405 \\
--\end{array}$ & $\begin{array}{c}3545 \\
--- \\
---\end{array}$ & $\begin{array}{c}3546 \\
3405 \\
---\end{array}$ & $\begin{array}{l}3545 \\
3405 \\
3244\end{array}$ & $\begin{array}{l}3545 \\
3405 \\
3245\end{array}$ & $\begin{array}{c}3548 \\
3406 \\
---\end{array}$ & $\begin{array}{l}\text { Asymmetric and symmetric O-H stretching bands of } \\
\text { both animal glue and gypsum (splitting of the band is } \\
\text { due to high concentration of gypsum in the sample). } \\
\text { N-H stretching band of animal glue is overlapped by } \\
\text { O-H bands. }\end{array}$ \\
\hline 2923 & 2926 & 2924 & 2925 & 2923 & 2924 & Asymmetric and symmetric $\mathrm{C}-\mathrm{H}$ stretching bands of \\
\hline 2854 & 2852 & 2853 & 2853 & 2851 & 2850 & aliphatic groups of animal glue. \\
\hline 1796 & 1798 & 1799 & -- & 1792 & 1792 & $\begin{array}{l}\text { Very weak band due to } \mathrm{C}=\mathrm{O} \text { group of calcite } \\
\text { (Calcite is present in low concentration). }\end{array}$ \\
\hline \multicolumn{3}{|c|}{ Very weak bands } & \multirow[b]{2}{*}{1734} & \multirow[b]{2}{*}{1734} & \multirow[b]{2}{*}{1734} & \multirow{2}{*}{$\mathrm{C}=\mathrm{O}$ stretching band of ester groups of fatty acids. ${ }^{*}$} \\
\hline 1734 & 1734 & 1734 & & & & \\
\hline \multicolumn{3}{|c|}{ Very weak bands } & \multirow[b]{2}{*}{1717} & \multirow[b]{2}{*}{1717} & \multirow[b]{2}{*}{1717} & \multirow{2}{*}{$\begin{array}{l}\mathrm{C}=\mathrm{O} \text { stretching band of acid due to slightly } \\
\text { hydrolysis of animal glue groups or presence of free } \\
\text { fatty acids. }\end{array}$} \\
\hline 1717 & 1717 & 1717 & & & & \\
\hline 1683 & 1684 & 1683 & 1684 & 1684 & 1684 & \multirow{2}{*}{$\begin{array}{l}\text { Region of carbonyl stretching band (amide I) of } \\
\text { animal glue. Splitting occurs due to } \mathrm{S}=\mathrm{O} \text { of } \mathrm{SO}_{4}^{-2} \text { of } \\
\text { gypsum. }\end{array}$} \\
\hline 1621 & 1623 & 1623 & 1621 & 1621 & 1621 & \\
\hline 1554 & 1556 & 1550 & 1558 & 1558 & 1558 & $\begin{array}{l}\text { Combination of C-N stretching band and } \mathrm{N}-\mathrm{H} \\
\text { bending band (amide II) of animal glue. }\end{array}$ \\
\hline 1450 & 1450 & 1450 & 1450 & 1450 & 1456 & Broad band due to combination between $\mathrm{C}-\mathrm{H}$ \\
\hline--- & --- & --- & 1418 & 1418 & 1418 & $\begin{array}{l}\text { bending vibration of animal glue (amide III) and } \\
\mathrm{CO}_{3}{ }^{-2} \text { stretching band of calcite. }\end{array}$ \\
\hline 1141 & 1141 & 1139 & 1139 & 1139 & 1140 & $\begin{array}{l}\mathrm{C}-\mathrm{O} \text { stretching of animal glue }+ \text { Asymmetric } \mathrm{SO}_{4}^{-2} \\
\text { stretching band of gypsum }\end{array}$ \\
\hline 874 & 875 & 874 & 875 & 875 & 875 & $\mathrm{O}-\mathrm{C}-\mathrm{O}$ bending band of carbonate group of calcite. \\
\hline 667 & 668 & 669 & 602 & 668 & 668 & $\mathrm{SO}_{4}^{-2}$ bending band of gypsum. \\
\hline
\end{tabular}


* Old glues contain small amounts of fatty acids (lipids), which would not be present in modern glue or gelatin (Skans and Michelsen, 1986 [13]; Mills and White, 1994 [14] \& Newman and Serpico, $2000[15])$.

Table (5): FTIR results of paint layer in El Safa Palace

\begin{tabular}{|c|c|c|c|}
\hline Sky colour & Greenish blue colour & Functional group & Comment \\
\hline$\sim 1650$ & $\sim 1650$ & $\mathrm{C}=\mathrm{O}$ stretching (amide $\mathrm{I}$ ) & \multirow{4}{*}{$\begin{array}{l}\text { These features are } \\
\text { characteristic for animal glue } \\
\text { (Derrick, et al. 1999) }\end{array}$} \\
\hline$\sim 1550$ & $\sim 1550$ & $\begin{array}{l}\mathrm{C}-\mathrm{N} \text { stretching and } \mathrm{N}-\mathrm{H} \\
\text { bending (amide II) }\end{array}$ & \\
\hline$\sim 1450$ & $\sim 1450$ & C-H bending (amide III ) & \\
\hline $3200-3500$ & $3200-3500$ & $\begin{array}{l}\mathrm{NH} \text { stretching peaks on } \\
\text { the broader bonded } \mathrm{O}-\mathrm{H} \\
\text { band }\end{array}$ & \\
\hline $\begin{array}{l}2926 \quad \text { and } \\
2855\end{array}$ & 2926 and 2855 & $\begin{array}{l}\text { Asymmetric and } \\
\text { symmetric C-H stretching } \\
\text { of aliphatic groups }\end{array}$ & \multirow{4}{*}{$\begin{array}{l}\text { These features indicated the } \\
\text { presence of oil (Derrick, et al. } \\
\text { 1999) }\end{array}$} \\
\hline 1735 & 1735 & $\begin{array}{l}\mathrm{C}=\mathrm{O} \text { stretching of ester } \\
\text { group }\end{array}$ & \\
\hline $\begin{array}{l}\sim 1464 \text { and } \\
721\end{array}$ & $\sim 1464$ and 721 & $\mathrm{C}-\mathrm{H}$ bending & \\
\hline $1110-1180$ & $1110-1180$ & C-O stretching & \\
\hline
\end{tabular}
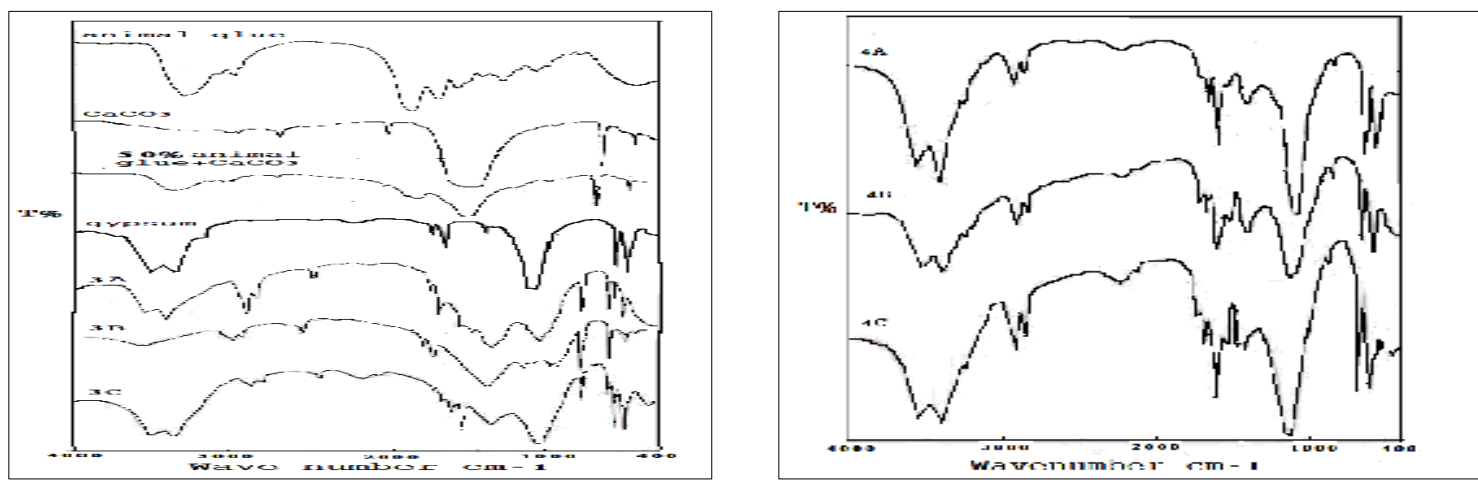

Fig. 7: Shows $\underline{\mathbf{a}}$ comparison between FTIR spectra of paintof layers Abdeen Palace, $\underline{\mathbf{b}}$ comparison of FTIR spectra samples of gilded layer samples of Abdeen Palace

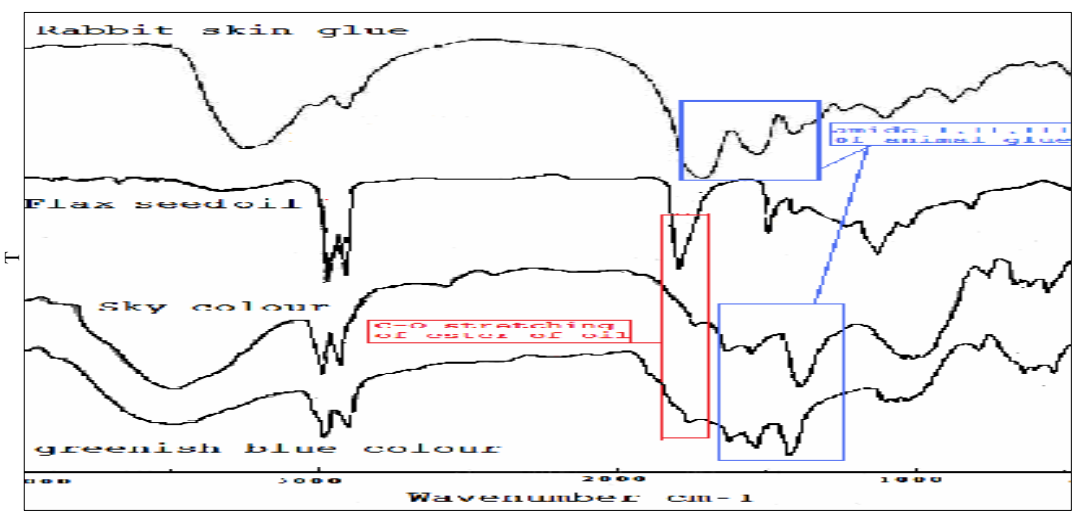

Fig 8 Shows comparison of FTIR spectra of paint layers samples of El Safa Palace

\subsection{The support:}

In Abdeen Palace: Wood is used as a support in the ceiling. In El Safa

Palace: The examination of the canvas fiber below the greenish blue and the black colors by L.O.M. proved that the fibers are from cotton (fig 6d). 


\section{Conclusion:}

The priming layer is a mixture of gypsum and calcite in Abdeen Palace, while in El Safa Palace it is a mixture of zincite, cerussite (lead carbonate) and gypsum. As for the paint layer in Abdeen palace, a mixture of mussicot and zincite was used to form the creamy yellow color, the light green color consists of Paratacamite $\mathrm{Cu}_{2} \mathrm{Cl}(\mathrm{OH})_{3}$, and the brown color consists of hematite. In El Safa Palace, sky color is a mixture of Prussian blue $\mathrm{Fe}_{4}\left[\mathrm{Fe}(\mathrm{Cn})_{6] 3}\right.$ and zincite, the greenish blue color is a mixture of Prussian blue and viridian in presence of zincite and gypsum, and amorphous carbon is responsible for the black color. The binder used to bind the color grains is animal glue in both palaces in addition to flax seed oil in the case of El Safa Palace. The canvas fibers used in El Safa Palace below the greenish blue and the black colors are cotton fibers. The gilded layer in Abdeen Palace is gold paper containing copper and zinc as impurities in both $4 A$ and $4 B$ samples and brass alloy in $4 C$ sample The results mentioned above will provide the conservators with the essential information needed to choose suitable materials and methods which can be used in conservation and restoration works

\section{References}

[1] Colinart, S., Delange, E., Pagès, S., (1996). Colours and Pigments of the Ancient Egypt, Techne, Vol. 4, pp: 29-45.

[2] Pagès, S., Colinart, S. and Coupry, C., (1999). Fabrication Processes of Archaeological Egyptian Blue and Green Pigments Enlightened by Raman Microscopy and Scanning Electron Microscopy, Journal of Raman Spectroscopy, Vol. 30, pp: 313-317.

[3] Cather, S., (1987). The Conservation of Wall Paintings, Proceedings of a Symposium Organized by the Courtauld Institute of Art and the Getty Conservation Institute, London.

[4] Arnold, A., (1977). Deterioration of Mural Painting and Sustained Care, in: La Matière Picturale: Fresque et Peinture Murale, (Cycle de course intensif sur les Sciences et Materiaux du Patrimonie Culturel, Ravello, Italy, pp: 113-122.

[5] Curteis, T., (2004). Environmental Conditions in Historic Churches: Examining their Effect on Wall Paintings and Polychrome Surfaces, Transactions of the Ecclesiastical Architects and Surveyors' Association, Vol. 5.

[6] Fleet, M., (1975): The Crystal Structure of Paratacamite, $\mathrm{Cu} 2(\mathrm{OH}) 3 \mathrm{Cl}$, Acta Cryst, Vol. 31, pp: 183-187.

[7] Jambor, J., Dutrizac, J., Roberts, A., Grice, J., and Szyma'nski, J., (1996). Clinoatacamite, a New Polymorph of $\mathrm{Cu} 2 \quad(\mathrm{OH}) 3 \mathrm{Cl}$, and its Relationship to Paratacamite and Anarakite, Can. Mineral, Vol. 34, pp: 61-72.

[8] Hradil, D., Grygar, T., Hradilova, J., and Bezdicka, P., (2003). Clay and Iron Oxide Pigments in the History of Painting, Applied Clay Science, Vol. 33, pp: 223-236.

[9] Cornell, R., and Schwertmann, U., (1996). The Iron Oxides: Structure, Properties, Reactions, Occurrence and Uses, VCH, Weinheim, Germany.

[10] Gettens, R., and Stout, G., (1966). Painting Materials: A Short Encyclopedia, Dover Publications, New York.

[11] Winter, J., (1983). The Characterization of Pigments Based on Carbon, Studies in Conservation, Vol. 28, pp: 49-66.

[12] Derrick, R., Stulik, D., and Landry, M., (1999). Infrared Spectroscopy in Conservation Science, the Getty Conservation Institute, Los Angeles.

[13] Skans, B., and Michelsen, P., (1986). Die Bedeutung von Fett in Tierleim für Malzwecke, Maltechnik, Vol. 96, pp: 63-71.

[14] Mills, J., and White, R., (1994). The Organic Chemistry of Museum Objects, Butterworth-Heinemann, London.

[15] Newman, R., and Serpico, M., (2000). Adhesive and Binders, in: Ancient Egyptian Materials and Technology, Cambridge Universe Press, London. 